\title{
Differential utilization of blood meal amino acids in mosquitoes
}

This article was published in the following Dove Press journal:

Open Access Insect Physiology

15 September 2009

Number of times this article has been viewed

\author{
Guoli Zhou \\ Roger Miesfeld \\ Department of Chemistry \\ and Biochemistry, University \\ of Arizona, Tucson, AZ, USA
}

Correspondence: Guoli Zhou

Department of Chemistry and

Biochemistry, University of Arizona, I04 I

E. Lowell Street, PO Box 210088, Tucson,

AZ 8572I-0088, USA

Tel +I 5206262344

Fax + I 52062 II697

Email guoli@email.arizona.edu
Abstract: Amino acids in the mosquito blood meal have two forms, protein-bound and plasma-free amino acids. To determine if the metabolic fate and flux of these two forms of blood meal amino acids are distinct, we fed mosquitoes eight $\left[{ }^{14} \mathrm{C}\right]$-labeled amino acids, seven of which are essential for mosquitoes (leucine, valine, isoleucine, phenylalanine, lysine, arginine, histidine), and one that can be readily converted to metabolic fuel (alanine). These ${ }^{14} \mathrm{C}$ tracer amino acids were either incorporated into an in vitro synthesized protein (protein-bound) and fed with blood to mosquitoes, or fed individually (free) with blood. In both forms, leucine had the highest relative flux with regard to synthesizing mosquito body lipid reserves, whereas histidine and arginine were the most highly excreted. We also found that protein-bound phenylalanine was incorporated at the highest rate into egg proteins, while plasma-free isoleucine was readily incorporated into egg proteins. Considering that plasma-free amino acids are rapidly absorbed and metabolized within the first eight hours post-blood meal, it is likely that the difference in egg protein incorporation reflects differential utilization of plasma-free isoleucine and phenylalanine. In order to determine if the metabolic fate of plasma-free isoleucine is affected by the origin of host blood or the number of gonotrophic cycles, we supplemented porcine and human blood with $\left[{ }^{14} \mathrm{C}\right]$-isoleucine in the absence or presence of $200 \mu \mathrm{M}$ unlabeled isoleucine. Our data show that host blood does not affect isoleucine incorporation into protein, and that plasma-free isoleucine incorporated into maternal proteins during the first gonotrophic cycle functions as an isoleucine reservoir for the second gonotrophic cycle.

Keywords: amino acid metabolism, metabolic flux, metabolic fate, gonotrophic cycle, host preference

\section{Introduction}

Anautogenous mosquitoes must take a blood meal to complete a gonotrophic cycle. The most abundant nutrient in the blood for mosquitoes is protein. Our previous study demonstrated that amino acids derived from the digestion of blood meal proteins are mainly used for both egg production and energy expenditure in Aedes aegypti. ${ }^{1}$ As all amino acids can be categorized as essential versus nonessential, or glycogenic versus ketogenic, different amino acids should have different metabolic flux and fate of carbon skeleton through different pathways. The relative metabolic flux of carbon skeleton from a mixture of dietary protein-bound amino acids through different pathways, which we previously described by using $\left[\mathrm{U}^{14} \mathrm{C}\right]$-algal proteins, ${ }^{1}$ is an integrated picture. To better understand the energetics and reproductive physiology of mosquitoes, it is necessary to pursue a detailed picture about the relative flux of individual proteinbound amino acids in the blood meal. submit your manuscript | www.dovepress.com

Dovepress 
In addition to proteins, the plasma of human blood contains a substantial amount of free amino acids, ranging from $13 \mu \mathrm{M}$ to $363 \mu \mathrm{M}$. $^{2}$ Accumulating evidence has shown that after the ingestion by mosquitoes, plasma-free amino acids in the meal can function as signaling molecules, eg, inducing early trypsin protein synthesis, ${ }^{3,4}$ regulating the retention of the meal in the midgut, ${ }^{5}$ and inducing phosphorylation of two known TOR target proteins, p70S6 kinase $(\mathrm{S} 6 \mathrm{~K})$ and the translational repressor 4E-binding protein (4E-BP) in Ae. aegypti. ${ }^{4}$ In addition, exogenous free amino acids can function as a regulator in mosquito reproduction. For instance, direct infusion of the hemocoel with free amino acids not only initiates ovarian development, but also regulates the number of maturing oocytes in several mosquito species. ${ }^{6}$ However, the direct role of plasma-free amino acids in energetics and reproduction in mosquitoes is unknown.

Adult female Ae. aegypti mosquitoes prefer to feed on human blood as evidenced by anthropophily. Earlier studies showed that adding the amino acid isoleucine to human blood enhanced fecundity of Ae. aegypti. ${ }^{7-10}$ Lower isoleucine in human blood, particularly free isoleucine in plasma, is thought to be responsible for lowered egg production when human blood is ingested..$^{9,10}$ However, another group of researchers found that female Ae. aegypti mosquitoes fed low isoleucine human blood can produce more eggs and accumulate higher energy reserves than cohorts fed high isoleucine mouse blood. ${ }^{11}$ To resolve these differences, it is necessary to quantitatively measure the direct role of free amino acid isoleucine in human blood in both the reproduction and the formation of energy reserves in Ae. aegypti.

In the present studies, we sought to investigate three aspects of amino acid metabolism in blood-fed Ae. aegypti mosquitoes: (1) to quantify the metabolic fate and flux of eight different $\left[{ }^{14} \mathrm{C}\right]$-amino acid-labeled green fluorescent protein species; (2) to quantify the metabolic fate and flux of these same eight $\left[{ }^{14} \mathrm{C}\right]$-amino acids in a plasmafree form; and (3) to quantitatively identify the direct role of plasma-free $\left[{ }^{14} \mathrm{C}\right]$-isoleucine in reproductive physiology of mosquitoes during a gonotrophic cycle. The results of these studies can be used to better understand the energetics and reproductive physiology of mosquito vectors during a gonotrophic cycle, and could potentially provide novel targets for effective control of mosquito population, and/or blockage of the transmission of mosquito-borne diseases by manipulating amino acid metabolic pathways.

\section{Materials and methods \\ Mosquitoes}

Aedes aegypti (L.) (Rockefeller) mosquitoes were used. Larvae were maintained on a diet consisting of equal proportions of rat chow (Sunburst Pet Foods, Phoenix, AZ, USA), lactalbumin hydrolysate (USB, Cleveland, $\mathrm{OH}$, USA) and yeast hydrolysate (USB) in batches of 2000 in a pan measuring $142 \times 76 \times 6 \mathrm{~cm}$, and containing about $4 \mathrm{~cm}$ of water. Female pupae were separated from males using a mosquito separator. Adult mosquitoes were routinely maintained at $28{ }^{\circ} \mathrm{C}, 70 \%-80 \%$ relative humidity and a photoperiod of 16:8 hours (L:D) on 3\% sucrose ad libitum (for free $\left[{ }^{14} \mathrm{C}\right]$-amino acid experiments) or $10 \%$ sucrose $\mathrm{ad}$ libitum (for GFP- $\left[{ }^{14} \mathrm{C}\right]$-amino acid experiments) for three days following eclosion.

\section{Materials}

We chose eight individual L-[U- $\left.{ }^{14} \mathrm{C}\right]$-amino acids: -isoleucine (Ile, specific activity: $11.5 \mathrm{GBq} / \mathrm{mmol}, 310 \mathrm{mCi}$ / mmol), -valine (Val, specific activity: $9.47 \mathrm{GBq} / \mathrm{mmol}$, $256 \mathrm{mCi} / \mathrm{mmol}$ ), -leucine (Leu, specific activity: $11.3 \mathrm{GBq} /$ mmol, $360 \mathrm{mCi} / \mathrm{mmol}$ ), -phenylalanine (Phe, specific activity: $17.0 \mathrm{GBq} / \mathrm{mmol}, 460 \mathrm{mCi} / \mathrm{mmol})$, -lysine monohydrochloride (Lys, specific activity: $11.8 \mathrm{GBq} / \mathrm{mmol}$, $318 \mathrm{mCi} / \mathrm{mmol}$ ), -arginine monohydrochloride (Arg, specific activity: $11.1 \mathrm{GBq} / \mathrm{mmol}, 300 \mathrm{mCi} / \mathrm{mmol})$, -histidine (His, specific activity: $11.6 \mathrm{GBq} / \mathrm{mmol}, 314 \mathrm{mCi} / \mathrm{mmol}$ ), and -alanine (Ala, specific activity: $5.99 \mathrm{GBq} / \mathrm{mmol}$, $162 \mathrm{mCi} / \mathrm{mmol}$ ) that were purchased from GE Healthcare (GE Healthcare UK Limited, Buckinghamshire, UK). In vitro protein synthesis system based on Escherichia coli lysate (RTS 100 E. coli HY Kit) was purchased from Roche Diagnostics GmbH (Roche Applied Science, Mannheim, Germany). All 20 nonradioactive L-amino acids were purchased from Sigma (Sigma Chemical Co, MO, USA). Pig blood was obtained from the University of Arizona animal farm and human blood was obtained from a volunteer.

\section{Experimental design}

In order to quantify the metabolic fate of a certain specific $\left[{ }^{14} \mathrm{C}\right]$-amino acid-labeled GFP protein, an in vitro protein synthesis system based on E. coli lysate from Roche was used to synthesize $\left[{ }^{14} \mathrm{C}\right]$-amino acid labeled GFP protein. The produced $\left[{ }^{14} \mathrm{C}\right]$-GFP protein was supplemented into an appropriate amount of pig blood and then fed to three-day-old females. The fed mosquitoes were maintained in a CARON 6010 Environmental Test Chamber (Caron Products and 
Services, Inc., Marietta, OH, USA) under the conditions of $28{ }^{\circ} \mathrm{C}, 70 \%-80 \% \mathrm{RH}$ and a photoperiod of $16: 8$ hours (L:D) on sugar meals ad libitum. In a second experiment designed to quantify the metabolic fate of free $\left[{ }^{14} \mathrm{C}\right]$-amino acids, a pig blood meal supplemented with a specific free $\left[{ }^{14} \mathrm{C}\right]$-amino acid was fed to three-day-old females. At the end of the gonotrophic cycle (120 hours post-blood meal, PBM), laid eggs and spent adults were collected to obtain $\left[{ }^{14} \mathrm{C}\right]$-labeled glycogen, lipid, protein, and amino acids. Lastly, we quantitatively identified the direct role of human blood-free amino acid isoleucine during the first and second gonotrophic cycle as well as the first two successive gonotrophic cycles, respectively. Four sub-experiments were performed. In sub-experiment 1 , about 100 three-day-old females were fed with human or pig blood supplemented with $20 \mu \mathrm{Ci}$ of $\left[{ }^{14} \mathrm{C}\right]$-Ile to quantify the utilization of free Ile during the 1 st gonotrophic cycle. In subexperiment 2 , about 100 three-day-old females were fed with human or pig blood supplemented with $200 \mu \mathrm{M}$ cold Ile and $20 \mu \mathrm{Ci}$ of $\left[{ }^{14} \mathrm{C}\right]$-Ile to quantify the utilization of high free Ile concentration in human blood during the 1st gonotrophic cycle. In sub-experiment 3, about 200 three-day-old females were fed with human blood without radioactivity to quantify the utilization of free Ile during the 2nd gonotrophic cycle. At the end of the 1st gonotrophic cycle (120 hours PBM), the fed females were allowed to lay the eggs, and subsequently fed with a human blood meal supplemented with $20 \mu \mathrm{Ci}$ of $\left[{ }^{14} \mathrm{C}\right]$-Ile. In sub-experiment 4 , about 150 three-day-old females were fed with human blood supplemented with $40 \mu \mathrm{Ci}$ of $\left[{ }^{14} \mathrm{C}\right]$-Ile to quantify the utilization of free Ile during the first successive two gonotrophic cycles. At the end of the 1st gonotrophic cycle (120 hours PBM), the fed females were allowed to lay the eggs, and subsequently fed with human blood meal without radioactivity.

\section{Preparation of $\left[{ }^{14} \mathrm{C}\right]$-amino acid-labeled GFP protein}

GFP is a globular protein with a molecular weight of $27 \mathrm{kDa}$ that contains all 20 naturally occurring amino acids. Moreover, it is susceptible to attack by carboxypeptidases and nonspecific proteases as are all other blood meal proteins. ${ }^{12}$ For example, recombinant GFP orally administered to rats can be rapidly degraded during simulated gastric digestion, ${ }^{13}$ indicating that GFP is digestible to the zoophagous animals. The relative content of the eight amino acids we tested, namely Ile, Val, Leu, Phe, Lys, Arg, His, and Ala, are present at a frequency of $5.0 \%, 7.1 \%, 8.0 \%, 5.5 \%, 8.4 \%, 2.5 \%, 4.2 \%$, and $3.4 \%$, respectively, in GFP. ${ }^{14,15}$ To incorporate these $\left[{ }^{14} \mathrm{C}\right]$-labeled amino acids one at a time into GFP, we used an in vitro protein synthesis system (RTS 100 E. coli $\mathrm{HY}$ kit) to synthesize the specific $\left[{ }^{14} \mathrm{C}\right]$-amino acid-labeled GFP protein according to the manufacturer's protocol (Roche Applied Scientific). Briefly, in a RNase-free tube, a $50 \mu \mathrm{l}$ of reaction was set up as follows: $0.6 \mu 1\left[{ }^{14} \mathrm{C}\right]-\mathrm{Ile}$, Val, Leu, Phe, Lys, Arg, His, or Ala ( $25 \mu \mathrm{Ci}$ each) in reconstitution buffer provided by the kit, $11.4 \mu \mathrm{l}$ of all other 19 cold amino acids in reconstitution buffer (each $0.6 \mu \mathrm{l}$ ), $12 \mu \mathrm{l}$ of $E$. coli lysate, $10 \mu \mathrm{l}$ of reaction mix, $1 \mu$ l GFP plasmid DNA $(1 \mu \mathrm{g} / \mu \mathrm{l})$ provided by the kit, $9 \mu \mathrm{l}$ of DEPC- $\mathrm{H}_{2} \mathrm{O}$, and $5 \mu \mathrm{l}$ of reconstitution buffer. The reaction was incubated at $30{ }^{\circ} \mathrm{C}$ for six hours. Each $\left[{ }^{14} \mathrm{C}\right]$-amino acid was first dried under the nitrogen gas and resuspended in $0.6 \mu \mathrm{l}$ of reconstitution buffer. To prepare all cold amino acid stock solution, for Ala, Arg, Asn, Asp, Ser, Gln, Glu, Gly, His, Pro, Thr, Val, and Ile, the amino acids were dissolved in the reconstitution buffer of the RTS E. coli HY kit to form a final concentration of $168 \mathrm{mM}$; for Leu, to $126 \mathrm{mM}$; for Met and Cys, they were made to $168 \mathrm{mM}$, but DTT was added to the final concentration of $4 \mathrm{mM}$ and $8 \mathrm{mM}$, respectively; for Tyr, it was dissolved in $60 \mathrm{mM}$ Hepes, 0.7 M KOH, while for Trp, it was in $60 \mathrm{mM}$ Hepes, $0.7 \mathrm{M}$ $\mathrm{HCl}$; for Phe, it was dissolved in $60 \mathrm{mM}$ Hepes, $\mathrm{pH} 7.45$ with ultrasound treatment, based on the instruction manual of RTS amino acid sampler (Roche Applied Science).

The newly synthesized $\left[{ }^{14} \mathrm{C}\right]$-GFP was purified with the trichloroacetic acid (TCA) precipitation method to remove all free $\left[{ }^{14} \mathrm{C}\right]$-amino acids. The average yield of the purified $\left[{ }^{14} \mathrm{C}\right]$-GFP was about $2 \times 10^{6}$ disintegrations per minute (DPM) and the average recovery of $\left[{ }^{14} \mathrm{C}\right]$-amino acid in GFP was about $4 \%$. The $\left[{ }^{14} \mathrm{C}\right]-\mathrm{GFP}$ was resuspended in $25 \mu \mathrm{l}$ of feeding buffer (100 mM NaHCO$\left.{ }_{3}, 150 \mathrm{mM} \mathrm{NaCl}, \mathrm{pH} 7.0\right)$. ${ }^{1}$ A confirmation of labeling GFP with $\left[{ }^{35} \mathrm{~S}\right]$-Met was performed as follows: in a $25 \mu \mathrm{l}$ of reaction, $6 \mu \mathrm{l}$ of amino acid mixture without Met, $0.75 \mu \mathrm{l}$ of $1.7 \mathrm{mM}$ Met, $5 \mu \mathrm{l}$ of L-[ $\left.{ }^{35} \mathrm{~S}\right]-\mathrm{Met}$ (1175 Ci/mmol, 43.5 TBq/mmol; MP Biomedicals, Solon, $\mathrm{OH}, \mathrm{USA}$ ), $6 \mu \mathrm{l}$ of $E$. coli lysate, $5 \mu \mathrm{l}$ of reaction mix, $1 \mu \mathrm{l}$ of GFP plasmid DNA $(1 \mu \mathrm{l} / \mu \mathrm{l})$, and $1.25 \mu \mathrm{l}$ of DEPC- $\mathrm{H}_{2} \mathrm{O}$ were combined and incubated at $30^{\circ} \mathrm{C}$ for six hours. The produced $\left[{ }^{35} \mathrm{~S}\right]$-GFP protein was visualized with $10 \%$ SDS-PAGE and radioautography using standard procedures.

\section{Preparation of $\left[{ }^{14} \mathrm{C}\right]$-amino acid or $\left[{ }^{14} \mathrm{C}\right]$ - amino acid-labeled GFP supplemented blood meal as well as mosquito feeding and sampling}

For the blood meal supplemented with free $\left[{ }^{14} \mathrm{C}\right]$-amino acid, about $20 \mu \mathrm{Ci}$ of $\left[{ }^{14} \mathrm{C}\right]$-amino acid (Ile, Leu, Val, Phe, 
Lys, Arg, His, and Ala) was individually dried under the nitrogen gas and resuspended with about $2 \mathrm{ml}$ of pig blood. For $\left[{ }^{14} \mathrm{C}\right]$-amino acid-labeled GFP supplemented blood meal, the produced $25 \mathrm{ul}$ of $2 \times 10^{6} \mathrm{DPM}\left[{ }^{14} \mathrm{C}\right]$-GFP was added to $0.3 \mathrm{ml}$ of pig blood and mixed very well. Before feeding to mosquitoes, all blood meals were added ATP to $5 \mathrm{mM}$ on an artificial feeder as described by Zhou and colleagues. ${ }^{1}$ About 100 three-day-old female mosquitoes were fed on the $\left[{ }^{14} \mathrm{C}\right]$-labeled blood meal for one hour in each experiment. The fed females were then treated as described by Zhou and colleagues. ${ }^{1}$ Briefly, five fed mosquitoes were frozen immediately after feeding for determination of the total amount of radioactivity consumed. Three groups of five fed females each were transferred into a scintillation vial immediately after the $\left[{ }^{14} \mathrm{C}\right]$-blood meal. At the end of the gonotrophic cycle, the contents of the vials were analyzed for $\left[{ }^{14} \mathrm{C}\right]$-waste. Another six groups of five fed females each were placed in a sealed plastic cup with a small piece of cotton soaked in $3 \%$ or $10 \%$ sucrose water and maintained until eggs had been laid. After the eggs were laid, the spent mosquitoes were analyzed for the incorporation of ${ }^{14} \mathrm{C}$ into mosquito carcass proteins, lipids, amino acids, glycogen, and sugars, and the eggs were analyzed for ${ }^{14} \mathrm{C}$ incorporation into proteins and lipids.

\section{Microseparation of proteins, lipids, amino acids, glycogen, sugars of mosquitoes}

Pools of $\left[{ }^{14} \mathrm{C}\right]$-labeled females were collected and dried at $100{ }^{\circ} \mathrm{C}$ for one hour and used separately for the microseparation of mosquito glycogen, lipid, protein, and amino acids. The dried mosquito samples were crushed with a glass rod in appropriate volume of saturated $\mathrm{Na}_{2} \mathrm{SO}_{4}$ in $\mathrm{H}_{2} \mathrm{O}$ and methanol, then extracted with methanol:chloroform $(1: 1 \mathrm{v} / \mathrm{v})$ into fractions containing protein, glycogen, total lipids, and mixture of amino acids and sugars. The fraction containing total lipids was passed through a column containing silicic acid to remove phospholipids from triacylglycerols. The combined aqueous extracts, which contain simple sugars and the amino acids, were mixed with cation-exchange resin to separate amino acids and sugars. The detailed procedures were referred to Zhou and colleagues. ${ }^{1}$

\section{Collection and microseparation of proteins and lipids of mosquito eggs}

Eggs were collected at 120 hours PBM. The spent females were dissected to collect any eggs retained in ovaries. The collected eggs and the carcasses were used for the microseparation of glycogen, sugars, lipid, protein and amino acids. ${ }^{1}$

\section{Collection and measurement of mosquito excretory waste}

According to our previous method, ${ }^{1}$ at the end of the gonotrophic cycle, the five females in the vials were removed from the vial. About $20 \mathrm{ml}$ of counting cocktail were added into each vial containing the accumulated excretory waste, and the vial was shaken several times to completely disperse the waste and then counted.

\section{Data analysis}

We are interested in studying the metabolic fate and relative metabolic flux. Thus, data obtained from 3-6 separate experimental samples and the various biochemical products were expressed as relative DPM (percentage of radioactivity, relative to initially consumed DPM per mosquito, named as $\mathrm{T}_{0}$ ). Unpaired $t$-test and one-way analysis of variance (ANOVA) with Tukey's multiple comparison test were used for comparison of various indices between different groups. The significance level was set at $P \leq 0.05$. All the statistical analyses and graphs were prepared using Graph Pad Prism 4 (Graph Pad Prism Software, Inc., San Diego, CA, USA) and SPSS for Windows (v11.5; SPSS Inc., Chicago, IL, USA).

\section{Results}

\section{Metabolic fate and flux of pig blood meal protein-bound amino acids}

In order to quantify the differential utilization of dietary protein-bound amino acids as a function of mosquito metabolism during a gonotrophic cycle, we chose eight different $\left[{ }^{14} \mathrm{C}\right]$-amino acids based on their metabolic roles in mosquito protein metabolism and used them to individually radiolabel GFP using an in vitro protein synthesis system. Seven of these amino acids are essential to the mosquito diet (Ile, Leu, Val, Phe, Lys, Arg, and His), whereas, Ala is a readily available source of metabolic fuel. Figure 1 shows the specificity and efficiency of radioactive GFP production using this cellfree transcription and translation system. Following TCA precipitation to remove unincorporated $\left[{ }^{14} \mathrm{C}\right]$-amino acids, female Ae. aegypti mosquitoes were fed with a pig blood meal supplemented with $\left[{ }^{14} \mathrm{C}\right]$-GFP through membrane feeding ${ }^{1}$ and the metabolic fate and flux of protein-bound $\left[{ }^{14} \mathrm{C}\right]$-amino acid were measured at the end of the gonotrophic cycle.

Figure 2 shows the metabolic flux of label at the end of the gonotrophic cycle. About $10 \%$ of GFP-bound $\left[{ }^{14} \mathrm{C}\right]$-Leu was 


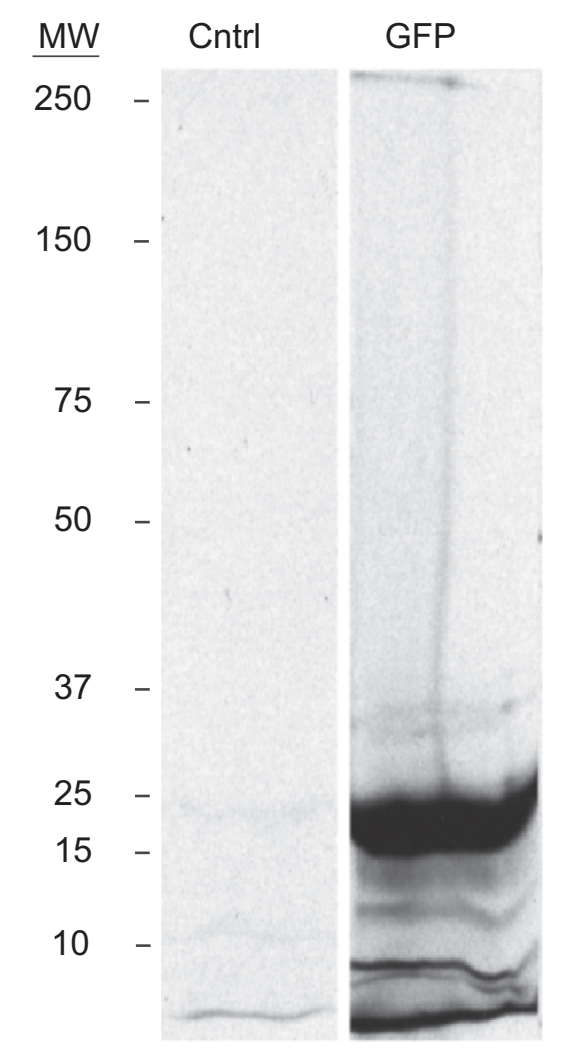

Figure I 10\% SDS-PAGE of radioactive GFP production by using $\left[{ }^{35} \mathrm{~S}\right]-$ Met to label GFP protein with an in vitro protein translation system. Lane marked with Cntrl: no GFP plasmid DNA template in the reaction; Lane marked with GFP: $\left[{ }^{35} \mathrm{~S}\right]-$ Met-GFP protein. About $10 \mu \mathrm{l}$ of reaction mixture was loaded to each lane. The incubation time of film for autoradiography was $30 \mathrm{~min}$.

used for carcass lipid reserve. This is the highest metabolic flux for carcass lipid reserve among all tested amino acids. The lowest metabolic flux for the lipid was observed with the GFP-His feeding experiment $(0.3 \%)$. About $21 \%-50 \%$ of amino acids including Ile, Leu, Val, Phe, Lys, and Arg derived from GFP were retained in carcass proteins, while only $11 \%$ and $14 \%$ of His and Ala from GFP went through this pathway, respectively. The highest flux into body amino acid pool occurred in the His-GFP feeding experiments (about 4.5\%), the second highest flux was from GFP-Arg and -Val (2.0\%), and only about $0 \%-1 \%$ of the rest amino acids appeared in the amino acid pool. About $2.7 \%$ of GFP-Ile was allocated into various sugars including trehalose, while the others invested $0.4 \%-1.0 \%$ only for this purpose. The two amino acids that showed the highest amount of excretion, were His and Arg, with $47 \%$ and $29 \%$ being excreted, respectively, which was significantly higher than what was observed for the other six amino acids $\left(5 \%-18 \%\right.$ of the ${ }^{14} \mathrm{C}$ label was found in the feces). For egg proteins, the greatest flux was from GFP-Phe $(27 \%)$, the lowest was from GFP-Ala (1\%), and the other GFP-amino acids invested about $5 \%-17 \%$ into this pathway.
All tested amino acids contributed much more to egg proteins than to egg lipids which ranged from only $0.6 \%-3.2 \%$ of the total ${ }^{14} \mathrm{C}$ label for each amino acid.

\section{Metabolic fate and flux of pig blood meal-free amino acids}

In order to quantify the differential utilization of different dietary free amino acid in both energetics and reproductive physiology of mosquitoes, we fed three-day-old female Ae. aegypti mosquitoes with a pig blood meal supplemented with free L-[U- $\left.{ }^{14} \mathrm{C}\right]-\mathrm{Ile}$, -Leu, -Val, -Phe, and-Lys, -Arg, -His, and -Ala, individually. As shown in Figure 3, we found that at the end of the 1 st gonotrophic cycle, about $65 \%$ of fed Ile was retained in carcass proteins. This was the highest flux compared to the other essential amino acids $(31 \%-43 \%)$ and nonessential amino acids (3\%-20\%). Similar to the result from GFP-labeled amino acid-feeding experiments, the highest flux for carcass amino acid pool was seen in the His and Arg feeding experiments (about $4 \%-6 \%$ ), while Leu has also the highest incorporation into carcass lipids (13\%) and the lowest was observed with the His feeding experiment $(0 \%)$. Significantly more His (53\%) and Arg (17\%) were excreted into waste than the other amino acids. Higher Ile flux was channeled into egg proteins (11\%), compared to other amino acids with the lowest flux occurring with Ala (1.0\%).

Based on these tracer ${ }^{14} \mathrm{C}$ labeling experiments, we conclude that the metabolic flux and fate of protein-bound amino acids, versus free amino acids, are different depending on specific amino acid utilization patterns over the time course of the first gonotrophic cycle.

\section{Utilization of free lle from human blood}

It has been known that the average concentration of free Ile is $65 \mu \mathrm{M}$ in human plasma ${ }^{2}$ and $131 \mu \mathrm{M}$ in plasma of pigs fed with soybean meal, ${ }^{16}$ and that this may result in differences in reproductive capacity of Ae. aegypti mosquitoes. ${ }^{9-11}$ To determine if this approximately twofold difference in free Ile concentration in human blood versus pig blood translates into distinct metabolic profiles, we measured the utilization of free $\left[{ }^{14} \mathrm{C}\right]$-Ile in a human blood meal, a human blood meal supplemented with $200 \mu \mathrm{M}$ Ile, or a pig blood meal during the first gonotrophic cycle. As shown in Figure 4A, there was no significant difference in the metabolic pattern of plasma Ile among these three groups. However, considering that the concentration of plasma-free Ile is different in three different treatments, we calculated the absolute amount of free Ile that was allocated into carcass proteins and egg proteins with the 

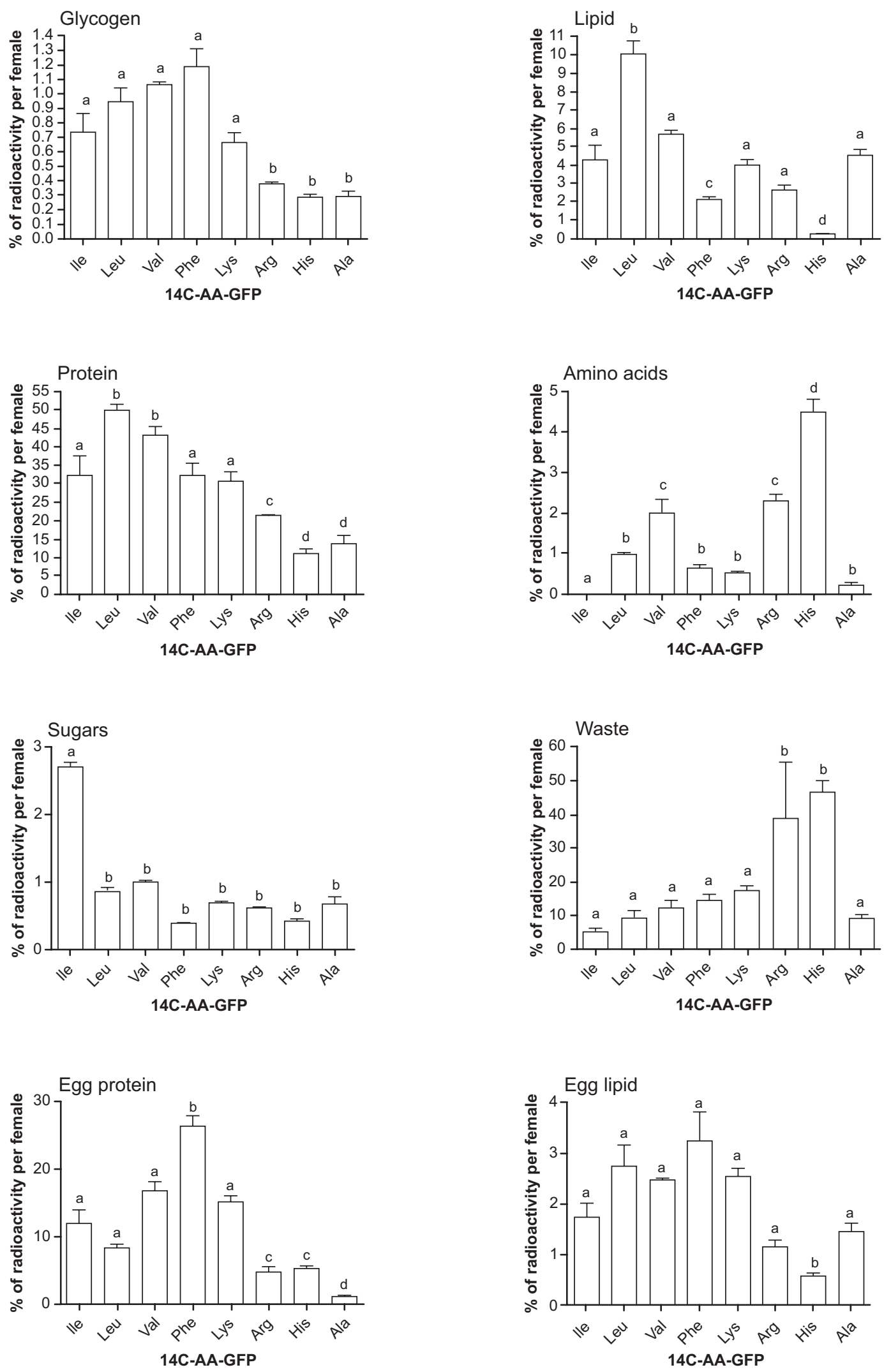

Figure 2 Metabolic fate and relative metabolic flux of protein-bound $\left[{ }^{14} \mathrm{C}\right]$-amino acid supplemented into pig blood in mosquitoes at the end of the gonotrophic cycle. Data are presented as percentage of DPM/mosquito from three to six independent experiments relative to T. One-way ANOVA with Tukey's multiple comparison test was used for statistical comparison. Bars with the same letters in each group are not significantly different, whereas, all pair-wise combinations of data from bars with different letters are significantly different $(P<0.05)$.

Abbreviation: DPM, disintegrations per minute. 
Dovepress

Blood meal amino acids in mosquitoes

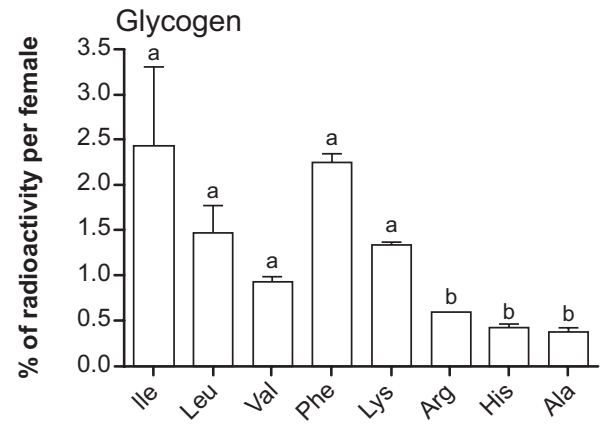

Free 14C-AA
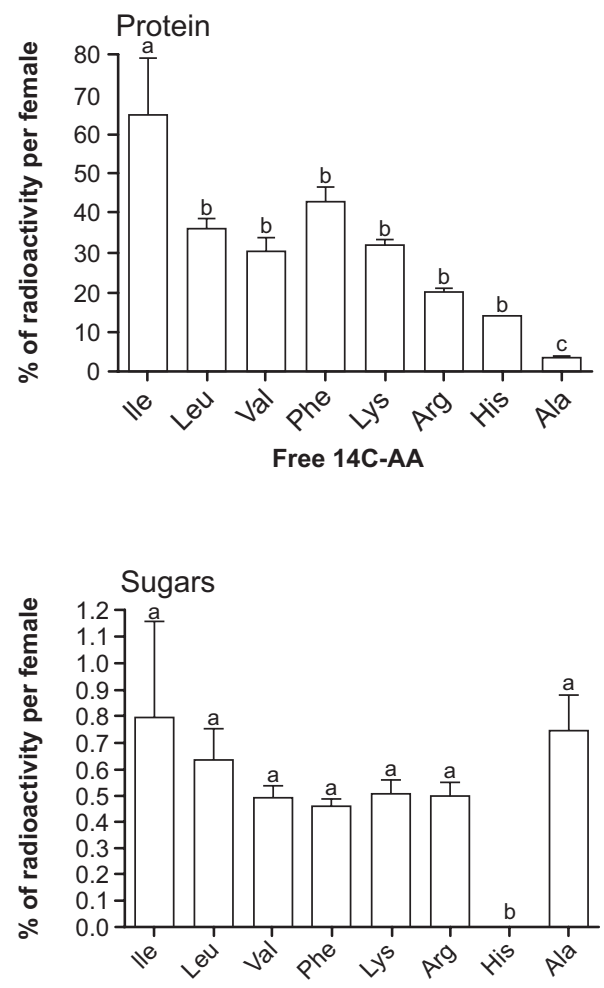

Free 14C-AA

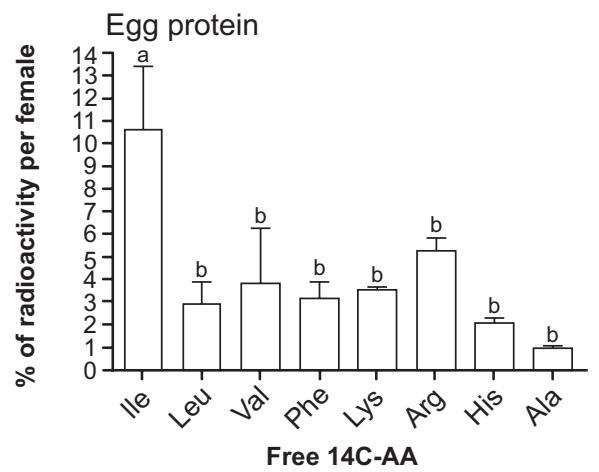

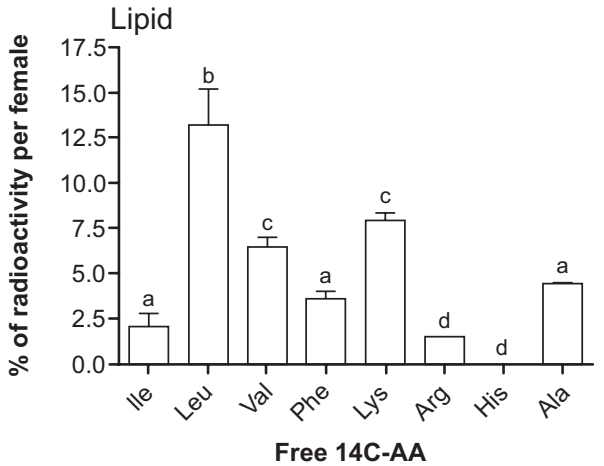
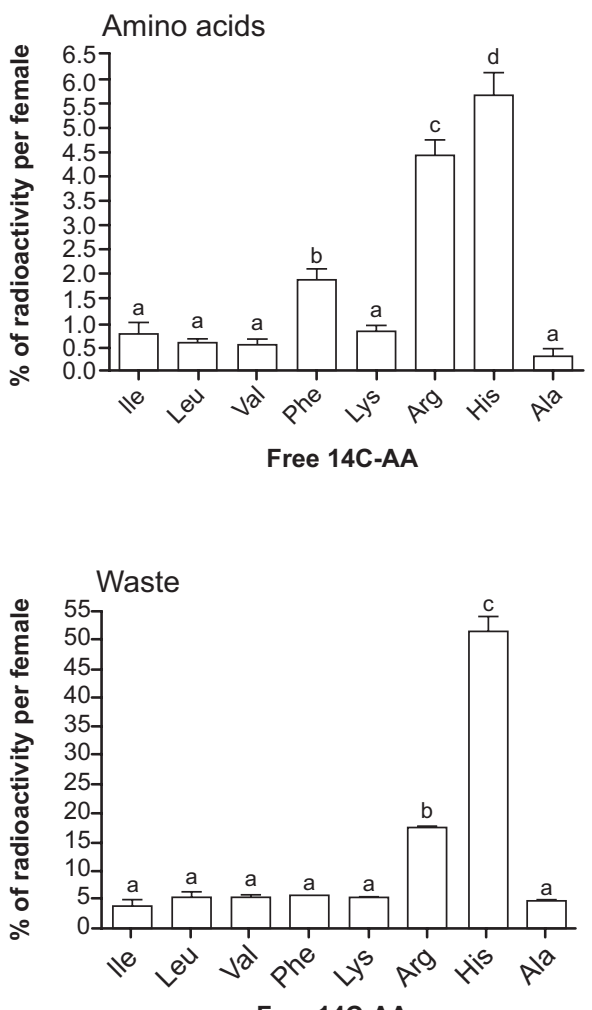

Free 14C-AA

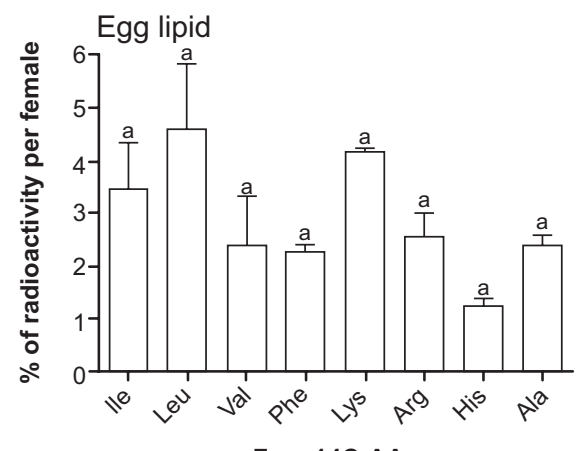

Free 14C-AA

Figure 3 Metabolic fate and flux of plasma-free $\left[{ }^{14} \mathrm{C}\right]$-amino acid supplemented into pig blood in mosquitoes at the end of the gonotrophic cycle. Data are presented as percentage of DPM/mosquito from three to six independent experiments relative to $T_{0}$. One-way ANOVA with Tukey's multiple comparison test was used for statistical comparison. Bars with the same letters in each group are not significantly different, whereas, all pair-wise combinations of data from bars with different letters are significantly different $(P<0.05)$.

Abbreviation: DPM, disintegration per minute.

Open Access Insect Physiology 2009:I

submit your manuscript | www.dovepress.com

Dovepress

7 
A

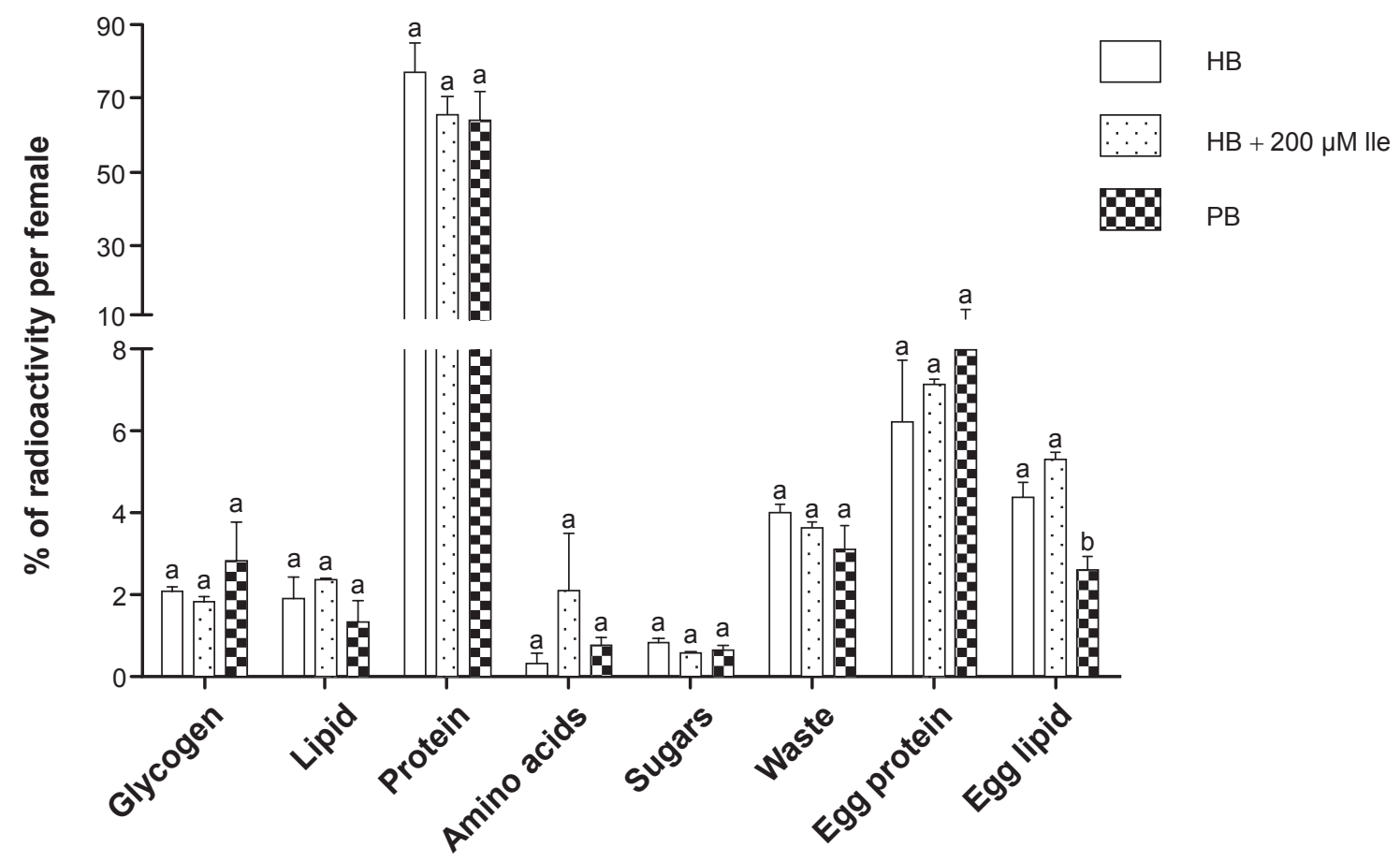

B

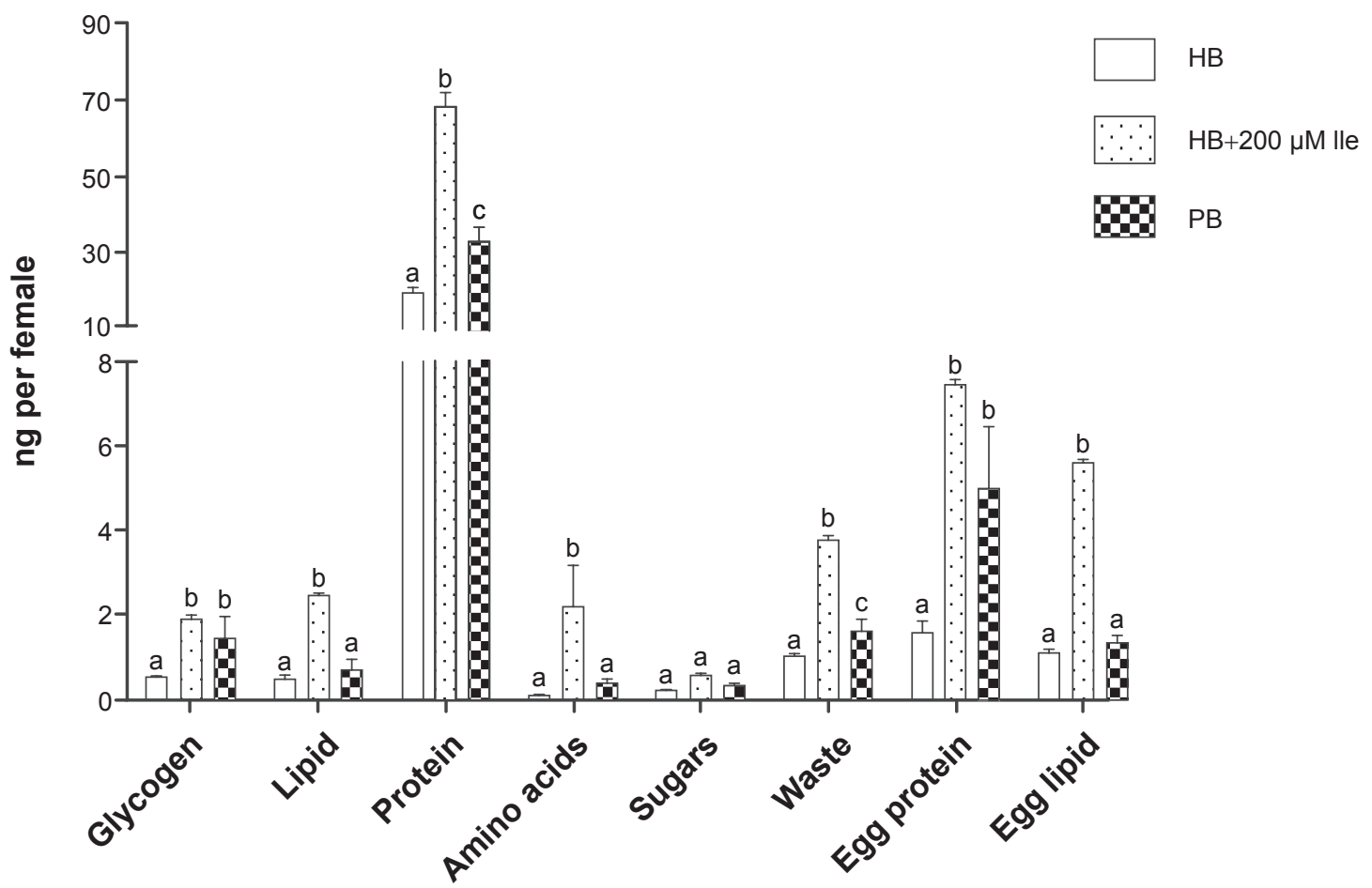

Figure 4 Comparison of free lle utilization in human blood, human blood supplemented with $200 \mu$ M of lle and pig blood. A) Data are presented as percentage of DPM/ mosquito from three to six independent experiments relative to $\mathrm{T}_{0}$; $\left.\mathbf{B}\right)$ Data are presented as $\mathrm{ng}$ of lle/mosquito from three to six independent experiments and the calculation was based on meal size $=3 \mu \mathrm{l}$, human plasma-free lle conc $=65 \mu \mathrm{M}$, pig plasma-free lle conc $=|3| \mu \mathrm{M}$, isoleucine molecular weight $=|3|$, and metabolic fluxes shown in Figure 4A. One-way ANOVA with Tukey's multiple comparison test was used for statistical comparison. Bars with the same letters in each group are not significantly different, whereas all pair-wise combinations of data from bars with different letters are significantly different $(P<0.05)$.

Abbreviation: DPM, disintegrations per minute. 
average meal size $(3 \mu \mathrm{l})$ in Ae. aegypti. ${ }^{17}$ As shown in Figure 4B, higher free Ile concentration allowed females to incorporate significantly more free Ile into both carcass and egg proteins.

We next examined the metabolic utilization of dietary free $\left[{ }^{14} \mathrm{C}\right]-$-Ile during the 2 nd gonotrophic cycle. Three-day-old female Ae. aegypti mosquitoes were fed a human blood meal without radioactivity during the 1 st gonotrophic cycle, and then given a human blood meal supplemented with $\left[{ }^{14} \mathrm{C}\right]$-Ile. As shown in Figure 5, comparison of the utilization of free Ile from human blood between the 1st and the 2 nd gonotrophic cycle revealed that the fluxes of Ile used for carcass proteins in the 2 nd cycle (58\%) were significantly smaller than that in the 1st cycle (77\%), while the flux of Ile used for egg protein in the 2 nd cycle (26\%) was significantly higher than that in the 1 st cycle ( $6 \%$ for human) (Figure 5). Correspondingly, the egg production during the 1 st gonotrophic cycle was smaller (42 eggs per female) than that during the 2 nd gonotrophic cycle (54 eggs per female) (data not shown).

These data indicate that plasma-free Ile incorporated into mosquito body proteins during the first gonotrophic cycle spares the plasma-free Ile from the second blood meal for synthesizing more egg proteins in the second gonotrophic cycle. Tracking the fate of $\left[{ }^{14} \mathrm{C}\right]$-Ile from the first blood meal during the first gonotrophic cycle at the end of the second gonotrophic cycle showed that about $35 \%$ of the dietary free Ile derived from the 1st gonotrophic cycle were still maintained in the carcass proteins, $2 \%$ in the carcass lipids, $5 \%$ in the egg proteins, $3 \%$ in the egg lipids, as well as $1 \%$ in the excretory waste, respectively (Figure 6). These results suggest that carcass protein-bound Ile derived from dietary free Ile during the 1st gonotrophic cycle can function as an Ile reservoir to benefit the 2 nd cycle in both energetics and reproductive physiology of mosquitoes.

\section{Discussion}

A blood meal is required for anautogenous female mosquitoes to complete a gonotrophic cycle. The most abundant group of nutrients in host blood for mosquitoes is amino acids, which include two forms, protein-bound and plasma-free amino acids. Our previous study revealed an integrated metabolic pattern of amino acid mixture from the blood meal proteins by feeding female mosquitoes with a pig blood meal supplemented with $\left[\mathrm{U}-{ }^{14} \mathrm{C}\right]$-algal proteins. ${ }^{1}$ To date, no studies

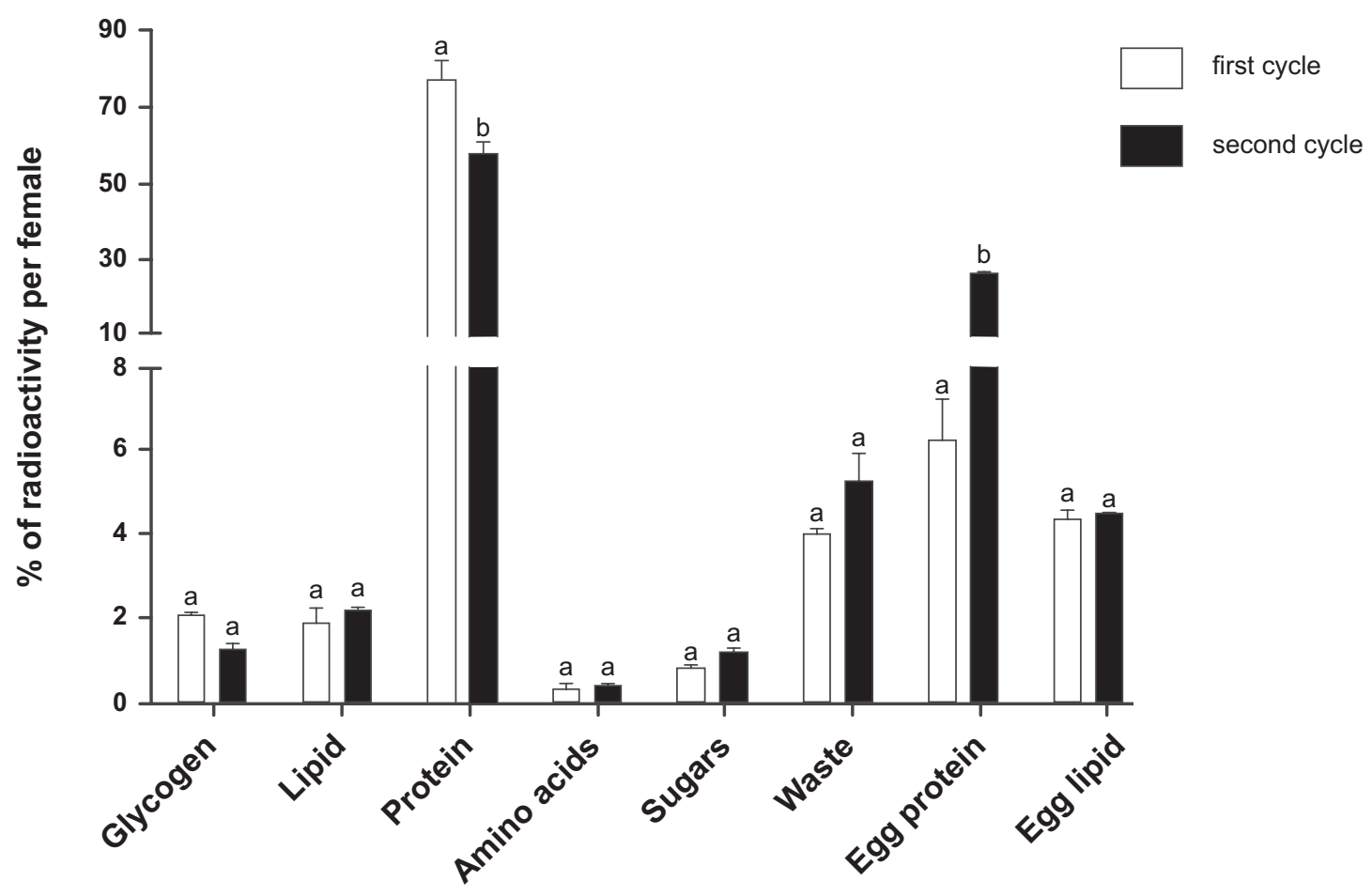

Figure 5 Comparison of free lle utilization in human blood between the Ist and 2nd gonotrophic cycle. Data are presented as percentage of DPM/mosquito from three to six independent experiments relative to $T_{0}$. Unpaired $t$-test was used for statistical comparison between two treatments. Bars with the same letters in each group are not significantly different, whereas, all pair-wise combinations of data from bars with different letters are significantly different $(P<0.05)$.

Abbreviation: DPM, disintegrations per minute. 


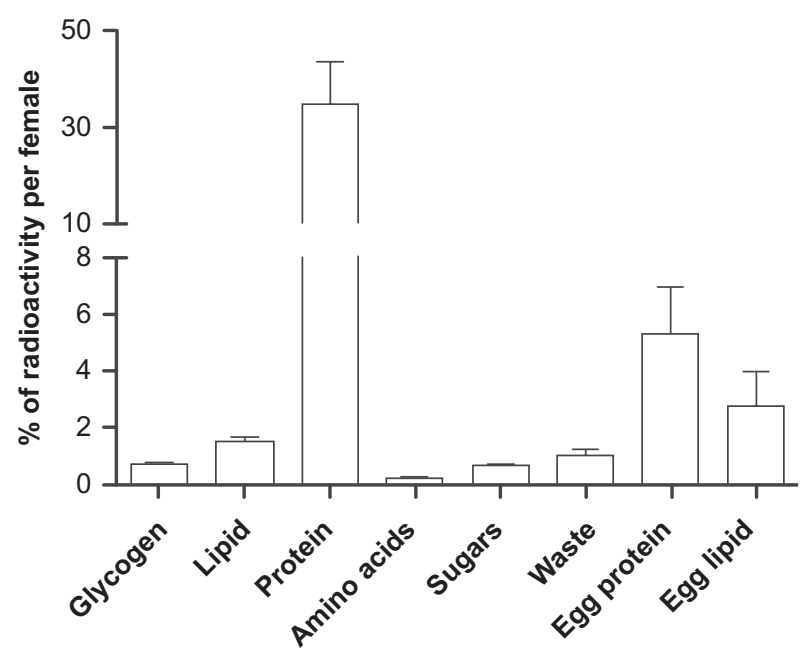

Figure 6 Utilization of free lle in human blood from the Ist gonotrophic cycle at the end of the 2 nd gonotrophic cycle. Data are presented as percentage of DPM/mosquito from three to six independent experiments relative to $T_{0}$.

Abbreviation: DPM, disintegrations per minute.

have reported the relative metabolic flux of individual protein-bound or free amino acids existing in host blood that is involved in both energetics and reproductive physiology of mosquitoes during a gonotrophic cycle.

We first investigated the metabolic fate of eight different $\left[{ }^{14} \mathrm{C}\right]$-amino acids in a GFP-bound or free status, separately, which were supplemented as radiolabeled metabolic tracers into pig blood that was fed directly to mosquitoes (Figures 2 and 3). For example, Leu, whether protein-bound or free, had the highest flux among the tested eight amino acids for synthesizing mosquito body lipid reserve at the end of the gonotrophic cycle (Figures 2 and 3). This reflects a biochemical property of Leu as an essential ketogenic amino acid. Our previous studies revealed that the maximal flux of lipogenesis from the meal amino acids occurs at 36 hours post $\left[\mathrm{U}-{ }^{14} \mathrm{C}\right]$-algal protein feeding. ${ }^{1}$ Although we did not measure the time course of metabolic flux of Leu into lipid store in this study, we speculate that the maximal conversion of Leu into lipid stores at 36 hours PBM should be much higher than that at the end of gonotrophic cycle. Interestingly, the major route for conversion of Leu carbon into lipid in rats is via citrate translocation from the mitochondria. ${ }^{18}$ If this is the case in mosquitoes, the citrate translocation could be a critical step for de novo lipogenesis from the meal amino acids during the gonotrophic cycle. On the other hand, Leu can also be a substantial precursor to polar lipids in rat brain. ${ }^{19,20}$ Whether mosquitoes also have such a pathway related to brain liponomics from Leu is unknown. In our present studies, the phospholipids, the component of membrane lipids, have been removed from the separated lipid fraction during the microseparation.

We also found that His was incorporated at the highest rate into the mosquito amino acid pool, with Arg being the second highest, regardless of the ${ }^{14} \mathrm{C}$ label originating in protein-bound or the free amino acid form (Figures 2 and 3). In crab, free His plays a role of intracellular buffering in muscles engaged in a short-term anaerobic activity. ${ }^{21}$ To date, no available information about the aerobic status of mosquitoes at the end of the gonotrophic cycle has been reported. However, available evidence has shown that in Drosophila, aerobic efficiency declines with age. ${ }^{22}$ Thus, free His might also play a role in intracellular buffering due to a decreased aerobic efficiency when mosquitoes are aging after a gonotrophic cycle. In humans, His supplementation of a low nitrogen diet can significantly improve total nitrogen retention when Arg was present in the diet. ${ }^{23}$ It is possible therefore, that high His and Arg in the free amino acid pool in mosquitoes might play a role in maintaining nitrogen balance in the body. This would be consistent with the finding that His and Arg were also excreted at the highest levels compared to the other six amino acids we examined and are similar to results from earlier studies in Ae. aegypti. ${ }^{24}$ It has been known that His is unusually abundant in hemoglobin, ${ }^{25,26}$ while L-Arg contains $32 \%$ nitrogen, the highest nitrogen content of any amino acids. ${ }^{27}$ Thus, our data reflect that mosquitoes have a huge buffering capability to maintain nitrogen balance by directly excreting His and Arg during a gonotrophic cycle.

Another interesting observation was that incorporation of $\left[{ }^{14} \mathrm{C}\right]$-labeled amino acids was much higher into egg proteins than into egg lipids (Figures 2 and 3). This might be due to the predominant use of larval lipid reserves for egg lipids during the first gonotrophic cycle so that blood meal amino acids can be shunted toward energy expenditure and other biosynthesis reactions. ${ }^{28}$ Amongst the amino acids that were incorporated at the highest rate into egg proteins, Phe was the most significant in terms of protein-bound amino acids, whereas Ile was highest among plasma-free amino acids. Our previous studies reported that plasma-free amino acids are rapidly absorbed and metabolized with the first eight hours PBM, ${ }^{1}$ suggesting that plasma-free Ile and protein-bound Phe play a role in both egg protein synthesis and body protein reconstruction during the early and late phases of a gonotrophic cycle, respectively.

Speilman and Wong observed a positive relationship between the proportion of females initiating oogenesis and the concentration of Ile in serum injected via enemas into the midgut of Ae. aegypti. ${ }^{29}$ It was shown that low Ile impaired 
DNA synthesis or replication, ${ }^{30,31}$ cell proliferation and cell function $^{32}$ as well as protein synthesis. ${ }^{33}$ Moreover, it has been known that cells undergo apoptosis when deprived of Ile. ${ }^{34}$ In contrast, protein-bound Phe is preferentially channeled to late protein synthesis during oogenesis. Usually, it takes some time for mosquitoes to digest blood proteins and then to release Phe or small peptides containing Phe. Recently, an aromatic nutrient transporter gene has been characterized from Anopheles gambiae. ${ }^{35}$ Further heterologous expression in Xenopus oocytes showed that it performs high-capacity uptake of Phe and its derivatives Tyr and L-DOPA, and it is strongly and specifically transcribed in absorptive and secretory parts of the larval alimentary canal and specific populations of central and peripheral neurons of visual-, chemo- and mechano-sensory afferents. ${ }^{35}$ This suggests that mosquito larvae have a substantial amount of Phe for their development. Our results indicate that in addition to larval food as a resource of Phe, adult blood meal proteins would be also a major resource of Phe for egg development to meet the upcoming cuticle hardening/coloring, wound curing, immune responses and melanization of pathogens.

Based on earlier reports that the concentration of Ile in human and pig blood impacts reproductive capacity of Ae. Aegypti, ${ }^{7-11}$ we analyzed $\left[{ }^{14} \mathrm{C}\right]$-Ile metabolism using supplemented human and pig blood meals. Our data demonstrated that both plasma-free Ile concentration and different host blood do not significantly affect the metabolic flux of free Ile in various metabolic pathways (Figure 4). However, such an unchanged flux allows females to incorporate significantly more meal free Ile into both carcass and egg proteins because of different Ile concentration (Figure 4), suggesting that mosquitoes do prefer to channel plasma-free Ile for both body and egg protein synthesis at the early stage of a gonotrophic cycle. In humans, decreased plasma and tissue Ile concentrations can impair protein synthesis, and then influence the function of rapidly dividing cells and short half-life proteins. ${ }^{36,37}$ Ile infusion stimulates the uptake of most amino acids by the liver in humans. ${ }^{37}$ In addition, in rats, oral administration of Ile increases skeletal muscle glucose uptake in vivo, and Ile significantly decreased AMPK $\alpha 2$ activity. ${ }^{38}$ However, whether mosquitoes also have such a mechanism in meal-free Ile metabolism is unknown.

Lastly, our studies indicate that plasma-free Ile incorporated into mosquito body proteins during the first gonotrophic cycle functions as an Ile reservoir and spares the plasma-free Ile from the second blood meal for synthesizing more egg proteins in the second gonotrophic cycle (Figure 5 and 6). As shown in Table 1, of the total contribution of plasma-free Ile to mosquito body proteins at the end of the 2 nd gonotrophic cycle, about $63 \%$ is from the 2 nd blood meal, and $37 \%$ is from the 1 st blood meal. In contrast, of the total contribution of plasma-free Ile incorporated into mosquito egg proteins at the end of the 2 nd gonotrophic cycle, about $83 \%$ is from the 2 nd blood meal, and $17 \%$ from the 1 st blood meal. This might be caused by the fact that in humans, in addition to lower plasma-free Ile, the whole blood including hemoglobin, albumin, and globulin is severely deficient in Ile. ${ }^{36,39-41}$ Thus, female mosquitoes have to make full use of the human plasma-free Ile for their reproduction, particularly early protein synthesis during oogenesis.

Taken together, our $\left[{ }^{14} \mathrm{C}\right]$-amino acid labeling studies in blood-fed Ae. aegypti mosquitoes, provide new insights into the relative contributions of many of the essential amino acids, and Ala, to active metabolic pools in the female mosquito during the first gonotrophic cycle. Moreover, our studies using $\left[{ }^{14} \mathrm{C}\right]$-Ile supplemented human or pig blood, indicate that differences in the endogenous concentration of Ile in the blood of these two host animals, does not affect overall Ile metabolism, suggesting that an approximately twofold difference in Ile concentration is not a molecular explanation for anthropophily in this mosquito species.

\section{Acknowledgments}

We thank Ms. Mary Hernandez for rearing mosquitoes, and Dr Jorge Zamora for help with the in vitro protein synthesis system. This work was supported by the National Institutes of Health grant R01-AI046451 to RLM. The authors report no conflicts of interest in this work.

\section{References}

1. Zhou G, Flowers M, Friedrich K, Horton J, Pennington J, Wells MA. Metabolic fate of $\left[{ }^{14} \mathrm{C}\right]$-labeled meal protein amino acids in Aedes aegypti mosquitoes. J Insect Physiol. 2004;50(4):337-349.

2. Adibi SA. Influence of dietary deprivations on plasma concentration of free amino acids of man. J Applied Physiol. 1968;25(1):52-57.

3. Noriega FG, Colonna AE, Wells MA. Increase in the size of the amino acid pool is sufficient to activate translation of early trypsin mRNA in Aedes aegypti midgut. Insect Biochem Mol Biol. 1999;29(3):243-247.

4. Brandon MC, Pennington JE, Isoe J,Zamora J, SchillingerAS, Miesfeld RL. TOR signaling is required for amino acid stimulation of early trypsin protein synthesis in the midgut of Aedes aegypti mosquitoes. Insect Biochem Mol Biol. 2008;38(10):916-922.

5. Caroci AS, Noriega FG. Free amino acids are important for the retention of protein and non-protein meals by the midgut of Aedes aegypti females. J Insect Physiol. 2003;49(9):839-844.

6. Uchida K, Oda T, Matsuoka H, et al. Induction of oogenesis in mosquitoes (Diptera: Culicidae) by infusion of the hemocoel with amino acids. J Med Ent. 2001;38(4):572-575. 
7. Greenberg J. Some nutritional requirements of adult mosquitoes (Aedes aegypti) for oviposition. J Nutr. 1951;43(1):27-35.

8. Lea AO, Dimond JB, Delong DM. Role of diet in egg development by mosquitoes (Aedes aegypti). Science. 1956;123(3203):890-891.

9. Chang YH, Judson CL. The role of isoleucine in differential egg production by the mosquito Aedes aegypti Linnaeus (Diptera: Culicidae) following feeding on human or guinea pig blood. Comp Biochem Physiol. 1977;57(1 Pt A):23-28.

10. Chang YH, Judson CL. Amino acid composition of human and guinea pig blood proteins and ovarian proteins of the yellow fever mosquito Aedes aegypti; and their effects on the mosquito egg production. Comp Biochem Physiol. 1979;62(3 Pt A):753-755.

11. Harrington LC, Edman JD, Scott TW. Why do female Aedes aegypti (Diptera: Culicidae) feed preferentially and frequently on human blood? J Med Ent. 2001;38(3):411-422.

12. Penna TC, Chiarini E, Machoshvili IA, Ishii M, Pessoa A. Intracellular release of recombinant green fluorescent protein (gfp(uv)) from Escherichia coli. Applied Biochem Biotech . 2002;(98-100):791-802.

13. Richards HA, Han C, Hopkins RG, Failla ML, Ward WW, Stewart CN. Safety assessment of recombinant green fluorescent protein orally administered to weaned rats. J Nutr. 2003;133(6):1909-1912.

14. Prasher DC, Eckenrode VK, Ward WW, Prendergast FG, Cormier MJ. Primary structure of the Aequorea victoria green-fluorescent protein. Gene. 1992;111(2):229-233.

15. Inouye S, Tsuji FI. Aequorea green fluorescent protein. Expression of the gene and fluorescence characteristics of the recombinant protein. FEBS Lett. 1994;341(2-3):277-280.

16. Puchal F, Hays VW, Speer VC, Jones JD, Catron DV. The free blood plasma amino acids of swine as related to the source of dietary proteins. J Nutr. 1962;(76):11-16.

17. Zhou G, Kohlhepp P, Geiser D, del Carmen Frasquillo M, Vazquez-Moreno L, Winzerling JJ. Fate of blood meal iron in mosquitoes. J Insect Physiol. 2007;53(11):1169-1178.

18. Vina JR, Williamson DH. Effects of lactation on L-leucine metabolism in the rat. Studies in vivo and in vitro. Biochem J. 1981;194(3):941-947.

19. Stillway LW, Weigand DA, Riefler JF, Buse MG. Leucine and isoleucine as in vitro precursors for lipid synthesis by rat aorta. Lipids. 1977;12(12):1012-1016.

20. Dhopeshwarker GA, Subramanian C. Lipogenesis in the developing brain: Utilization of radioactive leucine, isoleucine, octanoic acid and $\beta$-hydroxybutyric acid. Lipids. 1979;14(1):47-51.

21. Cameron JN. Intracellular buffering by dipeptides at high and low temperature in the blue crab Callinectes sapidus. J Exp Biol. 1989;(143):543-548.

22. Ross RE. Age-specific decrease in aerobic efficiency associated with increase in oxygen free radical production in Drosophila melanogaster. J Insect Physiol. 2000;46(11):1477-1480.

23. Anderson HL, Cho ES, Krause PA, Hanson KC, Krause GF, Wixom RL. Effects of dietary histidine and arginine on nitrogen retention of men. J Nutr. 1977;(107):2067-2077.

24. France KR, Judson CL. Nitrogen partitioning and blood meal utilization by Aedes aegypti (Diptera: Culicidae). J Insect Physiol. 1979;25(11):841-846.
25. Smith DWE, McNamara AL. Specialization of rabbit reticulocyte transfer RNA content for hemoglobin synthesis. Science. 1971; 171(971):577-579.

26. McNamara AL, Smith DWE. The function of the histidine tRNA isoaccepting species in hemoglobin synthesis. J Biol Chem. 1978;253(17):5964-5970.

27. Utagawa T. Production of arginine by fermentation. J Nutr. 2004; 134(10):2854S-2857S

28. Zhou G, Pennington JE, Wells MA. Utilization of pre-existing energy stores of female Aedes aegypti mosquitoes during the first gonotrophic cycle. Insect Biochem Mol Biol. 2004;34(9):919-925.

29. Speilman A, Wong J. Dietary factors stimulating oogenesis in Aedes aegypti. Biol Bull. 1974;(147):433-442.

30. Kohn A. Differential effects of isoleucine deprivation on cell motility, membrane transport and DNA synthesis in NIL 8 hamster cells. Exp Cell Res. 1975;94(1):15-22.

31. Tobey RA, Ley KD. Isoleucine-mediated regulation of genome replication in various mammalian cell lines. Cancer Res. 1971;(31):46-51.

32. Jakesz R, Smith CA, Aitken S, et al. Influence of cell proliferation and cell cycle phase on expression of estrogen receptor in MCF-7 breast cancer cells. Cancer Res. 1984;(44):619-625.

33. Lecavalier L, De Feo P, Haymond MW. Isolated hypoisoleucinemia impairs whole body but not hepatic protein synthesis in humans. Am J Physiol. 1991;(261):E578-E586.

34. Yen CL, Mar MH, Craciunescu CN, Edwards LJ, Zeisel SH. Deficiency in methionine, tryptophan, isoleucine, or choline induces apoptosis in cultured cells. J Nutr. 2002;(132):1840-1847.

35. Meleshkevitch EA, Assis-Nascimento P, Popova LB, et al. Molecular characterization of the first aromatic nutrient transporter from the sodium neurotransmitter symporter family. J Exp Biol. 2006;(209):3183-3198.

36. Olde Damink SWM, Dejong CHC, Deutz NEP, van Berlo CLH, Soeters PB. Upper gastrointestinal bleeding: an ammoniagenic and catabolic event due to the total absence of isoleucine in the haemoglobin molecule. Med Hypotheses. 1999;52(6):515-519.

37. Olde Damink SWM, Jalan R, Deutz NEP, et al. Isoleucine infusion during "simulated" upper gastrointestinal bleeding improves liver and muscle protein synthesis in cirrhotic patients. Hepatology. 2007;45(3):560-568.

38. Doi M, Yamaoka I, Nakayama M, Mochizuki S, Sugahara K, Yoshizawa F. Isoleucine, a blood glucose-lowering amino acid, increases glucose uptake in rat skeletal muscle in the absence of increases in AMP-activated protein kinase activity. J Nutr. 2005;(135):2103-2108

39. Hill RJ, Konigsberg W. The structure of human hemoglobin. J Biol Chem. 1962;237(10):3151-3156.

40. Lawn RM, Efstratiadis A, O'Connell C, Maniatis T. The nucleotide sequence of the human beta-globin gene. Cell. 1980;21(3):647-651.

41. Olde Damink SWM, Jalan R, Deutz NEP, Hayes PC, Soeters PB. Protein synthesis is severely diminished following a simulated upper GI bleed in patients with cirrhosis. $J$ Hepatology. 2008;49(5):726-731.
Open Access Insect Physiology

\section{Publish your work in this journal}

Open Access Insect Physiology is an international, peer-reviewed, open access journal publishing original research, reports, reviews and commentaries on all areas of insect physiology. The manuscript management system is completely online and includes a very quick and fair peer-review system, which is all easy to use.

\section{Dovepress}

Visit http://www.dovepress.com/testimonials.php to read real quotes from published authors. 